\title{
Active matrix metalloproteinase-7 is associated with invasion in buccal squamous cell carcinoma
}

\author{
Hui-Ching Chuang ${ }^{1,2,3}$, Chih-Ying Su ${ }^{1,2}$, Hsuang-Ying Huang ${ }^{2,4}$, Chao-Cheng Huang ${ }^{2,3,4}$, \\ Chih-Yen Chien ${ }^{1,2}$, Yung-Ying $\mathrm{Du}^{5}$ and Jiin-Haur Chuang ${ }^{3,5}$
}

${ }^{1}$ Department of Otolaryngology, Chang Gung Memorial Hospital-Kaohsiung Medical Center, Chang Gung University College of Medicine, Taiwan; ${ }^{2}$ Kaohsiung Chang Gung Head and Neck Oncology Group, Chang Gung Memorial Hospital-Kaohsiung Medical Center, Chang Gung University College of Medicine, Taiwan; ${ }^{3}$ The Graduate Institute of Clinical Medical Sciences, Chang Gung University College of Medicine, Kaohsiung, Taiwan; ${ }^{4}$ Department of Pathology, Chang Gung Memorial Hospital-Kaohsiung Medical Center, Chang Gung University College of Medicine, Taiwan and ${ }^{5}$ Department of Surgery, Division of Pediatric Surgery, Chang Gung Memorial Hospital-Kaohsiung Medical Center, Chang Gung University College of Medicine, Taiwan

\begin{abstract}
Protein microarrays have shown that matrix metalloproteinase-7 is upregulated in head and neck squamous cell carcinomas, but its role in local tissue invasion is still uncertain. We investigated the expression of active matrix metalloproteinase-7, using tissue microarray, immunohistochemistry, and western blotting, in oral tissues from 24 patients with buccal squamous cell carcinoma, and correlated the findings with clinicopathological features. Normal buccal tissue samples from the same patients, obtained at sites at least $1 \mathrm{~cm}$ from tumor tissue, served as normal controls. Total matrix metalloproteinase-7 was detected on western blots in 9 of $15(60 \%)$ tumor tissue samples and in 2 of $15(13 \%)$ normal mucosal samples; this difference was significant $(P=\mathbf{0 . 0 0 8})$. Moreover, the active matrix metalloproteinase-7 was expressed only in eight of the nine $(89 \%)$ tumor samples that expressed matrix metalloproteinase-7, and in none of the normal tissue samples, regardless of the expression status of the pro-matrix metalloproteinase-7. Immunostaining of matrix metalloproteinase-7 was observed histologically in both tumor and nonneoplastic epithelium, but immunostaining of active matrix metalloproteinase-7 was present only in tumor nests. Expression of active matrix metalloproteinase-7 was associated with larger tumor size $(P=0.022)$ and was significantly higher in buccal squamous cell carcinoma with adjacent skin or bone invasion $(P=0.036)$. In conclusion, active matrix metalloproteinase-7 expression was associated with more aggressive buccal squamous cell carcinomas. Modern Pathology (2008) 21, 1444-1450; doi:10.1038/modpathol.2008.99; published online 17 October 2008
\end{abstract}

Keywords: buccal squamous cell carcinoma; immunohistochemistry; MMP-7 (matrilysin-1); western blotting

Squamous cell carcinoma of the oral cavity is a major health problem worldwide, and ranks fourth among the top 10 malignancies seen in the male population of Taiwan, according to the 2005 domestic cancer registry. ${ }^{1}$ It occurs mainly in the buccal mucosa and in the tongue, ${ }^{2}$ where these

Correspondence: Dr C-Y Su, MD, Department of Otolaryngology, Chang Gung Memorial Hospital-Kaohsiung Medical Center, 123, Ta-Pei Road, Niao-Song Hsiang, Kaohsiung County 833, Taiwan and Dr J-H Chuang, MD, Department of Surgery, Division of Pediatric Surgery, Chang Gung Memorial Hospital-Kaohsiung Medical Center, 123, Ta-Pei Road, Niao-Song Hsiang, Kaohsiung County 833, Taiwan.

E-mails: voicebeautysu@yahoo.com.tw; usgniy@cgmh.org.tw and jhchuang@adm.cgmh.org.tw

Received 28 January 2008; revised and accepted 05 May 2008; published online 17 October 2008 tumors grow rapidly and involve surrounding tissues, including adjacent muscle, bone, and cheek skin. Advanced oral squamous cell carcinoma that invades the mandibular bone is associated with a higher mortality. ${ }^{3}$ Despite refined surgical techniques, the prognosis for oral squamous cell carcinoma has remained almost unchanged for the past 10 years. The mortality rate of male patients with oral cavity cancer in Taiwan was 15.9 of 100000 in 2004, 1.5 times that of 10 years ago. ${ }^{1}$

Tumorigenesis is a complex, multistep process. Degradation of the basement membrane and invasion of the underlying connective tissue by neoplastic cells are recognized as fundamental steps in the development of many epithelial cancers. Degradation of extracellular matrix components is primarily controlled by a balance among the proteolytic 
enzymes called matrix metalloproteinases (MMPs) and the corresponding tissue inhibitors of MMPs (TIMPs). MMPs are a family of zinc-dependent proteolytic enzymes involved in the degradation of the extracellular matrix in various tissues, including bone. The expression of MMPs in head and neck cancers has been reported. ${ }^{4-14}$ Those studies demonstrated that immunoreactive MMP-2 and MMP-9 staining was stronger in patients with lymph node metastasis and was associated with lower survival rates. ${ }^{11-14}$

MMP-7 is one of the few MMPs overexpressed by carcinoma cells rather than by stromal cells. ${ }^{15-17}$ According to a recent protein microarray study, MMP-7 was significantly upregulated in head and neck squamous cell carcinoma tissues. ${ }^{18}$ However, the contribution of active MMP-7 vs MMP-7 in the progression of oral cancer has not been determined..$^{19-23}$ In the present study, we used tissue microarray together with immunohistochemistry and western blotting to analyze the expression of active MMP-7 in buccal squamous cell carcinoma and in normal tissues from the same patients and correlated these findings with clinicopathological features of buccal squamous cell carcinoma.

\section{Materials and methods}

\section{Patients and Clinicopathological Data}

The study included 24 male patients with buccal squamous cell carcinoma who underwent primary surgical resection by one of two surgeons (CHC or CYC) at Chang Gung Memorial Hospital-Kaohsiung Medical Center between 2005 and 2007. Paired sets of normal and tumor tissues were obtained during surgery and were placed in liquid nitrogen as soon as possible after removal. The tissue was stored at $-80^{\circ} \mathrm{C}$ until processing. The average age of the patients was 52.4 years (range, 37-73 years). The mean follow-up time for all of the patients was 18 months (range, 7-31 months).

Clinicopathological information, obtained retrospectively from clinical records, included primary tumor size $(T)$, nodal status $(N)$, histological grade, tumor thickness, and the presence of tumor necrosis, perineural invasion, vascular invasion, or adjacent tissue invasion (Table 1). The TNM status was classified according to the 2002 American Joint Committee on Cancer system. This study was executed after approval by the Ethics and Clinical Research Committee of Chang Gung University, and informed consent was obtained from the patients or from their legal guardians.

\section{Western Blotting}

Protein lysates for western blotting were isolated from 15 paired sets of normal and tumor tissues of buccal squamous cell carcinoma patients, using a
Table 1 Clinicopathological features in 24 patients with buccal squamous cell carcinoma

\begin{tabular}{|c|c|c|}
\hline Variables & No. of cases & $\%$ \\
\hline \multicolumn{3}{|l|}{ Tumor stage $(A J C C)^{\mathrm{a}}$} \\
\hline Stage I & 5 & 21 \\
\hline Stage II & 4 & 17 \\
\hline Stage III & 3 & 12 \\
\hline Stage IV & 12 & 50 \\
\hline \multicolumn{3}{|l|}{ Nodal status ${ }^{\mathrm{a}}$} \\
\hline No & 17 & 71 \\
\hline N1 & 4 & 17 \\
\hline N2 & 3 & 12 \\
\hline \multicolumn{3}{|l|}{ Differentiation } \\
\hline Well & 19 & 79 \\
\hline Moderate & 5 & 21 \\
\hline \multicolumn{3}{|l|}{ Invasion tissue } \\
\hline Negative & 15 & 63 \\
\hline Positive (skin or bone) & 9 & 37 \\
\hline \multicolumn{3}{|l|}{ Tumor necrosis } \\
\hline Negative & 15 & 63 \\
\hline Positive & 9 & 37 \\
\hline \multicolumn{3}{|l|}{ Vascular invasion } \\
\hline Negative & 20 & 83 \\
\hline Positive & 4 & 17 \\
\hline \multicolumn{3}{|l|}{ Perineural invasion } \\
\hline Negative & 17 & 71 \\
\hline Positive & 7 & 29 \\
\hline \multicolumn{3}{|l|}{ Recurrence } \\
\hline No & 21 & 88 \\
\hline Yes & 3 & 12 \\
\hline \multicolumn{3}{|l|}{ Distal metastasis } \\
\hline No & 23 & 96 \\
\hline Yes & 1 & 4 \\
\hline \multicolumn{3}{|l|}{ Survival status } \\
\hline Alive & 21 & 88 \\
\hline Death & 3 & 12 \\
\hline
\end{tabular}

${ }^{a}$ According to the 2002 American Joint Committee on Cancer (AJCC) system.

protein extraction reagent (Pierce Biotechnology, Rockford, IL, USA). The protein concentrations of the samples were determined using a Bio-Rad protein assay (Bio-Rad Laboratories, Hercules, CA, USA). Total protein $(30 \mu \mathrm{g})$ from each sample was separated by SDS-PAGE using $12.5 \%$ gels. The separated proteins were transferred from the gels and immobilized on PVDF membranes. To block nonspecific reactivity, the membranes were treated for $1 \mathrm{~h}$ with phosphate-buffered saline (PBS) containing $3 \%$ dry milk. The membranes were incubated overnight with MMP-7 antibody (kindly provided by Assistant Professor Wei-Hsuan Yu, Institute of Biochemistry and Molecular Biology, National Taiwan University). After washing in PBS, the membranes were incubated with horseradish 
peroxidase-conjugated goat anti-rabbit antibody (Santa Cruz Biotechnology, Santa Cruz, CA, USA) for $1 \mathrm{~h}$. Signals were detected using an ECL western blotting kit (Amersham Biosciences, Buckinghamshire, UK). The level of $\beta$-actin was detected as an internal control.

\section{Immunohistochemistry of MMP-7 and Active MMP-7}

Paraffin-embedded tissue sections ( $5 \mu \mathrm{m}$-thick) of tumors were deparaffinized and rehydrated. Endogenous peroxidase activity was inactivated with $3 \%$ hydrogen peroxide for $15 \mathrm{~min}$, and the samples were processed in a microwave oven in $10 \mathrm{mM}$ citrate buffer ( $\mathrm{pH}$ 6.0) to unmask epitopes. After antigen retrieval, the sections were incubated with diluted primary antibodies for $2 \mathrm{~h}$, followed by washing with PBS. Two different antibodies against MMP-7 were purchased from Oncogene Research Products (San Diego, CA, USA). The Ab-4 rabbit anti-humanMMP-7 monoclonal antibody, which recognizes both pro- and active forms of MMP-7, was diluted 1:100 in PBS. The Ab-2 mouse antibody, raised against a synthetic peptide corresponding to amino acids 78-82 of human MMP-7, recognizes only the active form of MMP-7 and was diluted 1:10 in PBS, according to the manufacturer's instructions. Horseradish peroxidase/Fab polymer conjugate was then applied to the sections for $30 \mathrm{~min}$. After extensive washing, the sections were incubated for $3 \mathrm{~min}$ with the peroxidase substrate diaminobenzidine, counterstained with Gill's hematoxylin, and mounted in mounting medium.

\section{Tissue Microarray and Immunohistochemistry of Active MMP-7}

Surgical specimens of all 24 patients were fixed in formalin and embedded in paraffin. Slides were stained with hematoxylin and eosin and were reviewed by a pathologist (HYH), who marked well-preserved areas. Three cylindrical cores, each measuring $0.6 \mathrm{~mm}$ in diameter, were obtained from every donor block, using a tissue microarray workstation (MTA-1; Beecher Instruments, Silver Spring, MD, USA). Cores, including those from submandibular gland control tissue, were arrayed in a new paraffin block. Tissue sections ( $3 \mu \mathrm{m}$ thick) were mounted on poly-L-lysine-coated slides, deparaffinized, and incubated overnight in an oven at $37^{\circ} \mathrm{C}$. Staining was performed as described above.

\section{Scoring of Immunoreactivity for Active MMP-7}

Active MMP-7 staining intensity was rated on a four-grade scale: 0 , absence of immunostaining in cells; $1+$, weak staining in cells; $2+$, moderate cytoplasmic staining in groups of cells; and $3+$, strong cytoplasmic staining in most cells. For statistical analysis of active MMP-7 immunostaining, the samples were divided into two groups: low expression (grades 0, 1, and 2) and high expression (grade 3).

\section{Statistical Analysis}

Clinicopathological factors that were evaluated included age ( $\geqq 50$ years vs $<50$ years), tumor staging, tumor size, presence or absence of neck metastasis, differentiation (well differentiated vs moderately differentiated), tumor thickness, tumor necrosis, perineural invasion, and vascular invasion. Categorical data were analyzed with Fisher's exact probability test and with $\chi^{2}$-tests for linear trends. A $P$-value less than 0.05 was regarded as statistically significant.

\section{Results}

\section{Active MMP-7 Protein was Expressed Only in Cancer Tissues}

MMP-7 protein was expressed in 9 of $15(60 \%)$ tumor samples, and in 2 of $15(13 \%)$ normal buccal mucosal samples $(P=0.008$; Figure 1$)$. The proMMP-7 was present in both normal buccal mucosa and in 3 of 9 $(33 \%)$ tumor tissues, whereas the active MMP-7 was present only in 8 of the 9 (89\%) MMP-7-positive tumor tissues. Normal buccal tissues did not express the active MMP-7.

Immunohistochemistry also showed that nonneoplastic epithelial cells were stained by the Ab-4 antibody, which recognized both the pro- and the active forms of MMP-7, but not by the Ab-2 antibody, which recognized only the active form. In contrast, the tumor tissue could be stained by both Ab-4 and Ab-2 antibodies (Figure 2). The results clearly indicate that active MMP-7 was present only in buccal squamous cell carcinoma cancer tissues, and not in normal tissues. We therefore used the Ab-2 antibody in a tissue

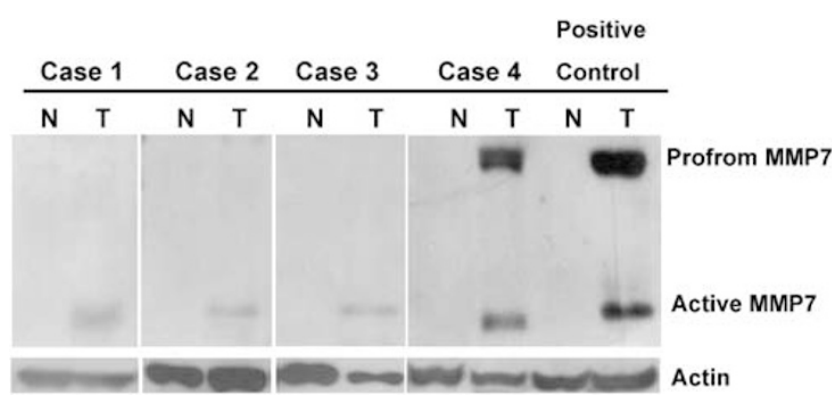

Figure 1 Western blot analysis of MMP-7 protein in normal and tumor tissue. Active MMP-7 expression is exclusively in tumor tissue. Actin is used as the control for equal loading of the tissue samples (bottom). Colorectal normal and tumor tissue are used as positive control. 

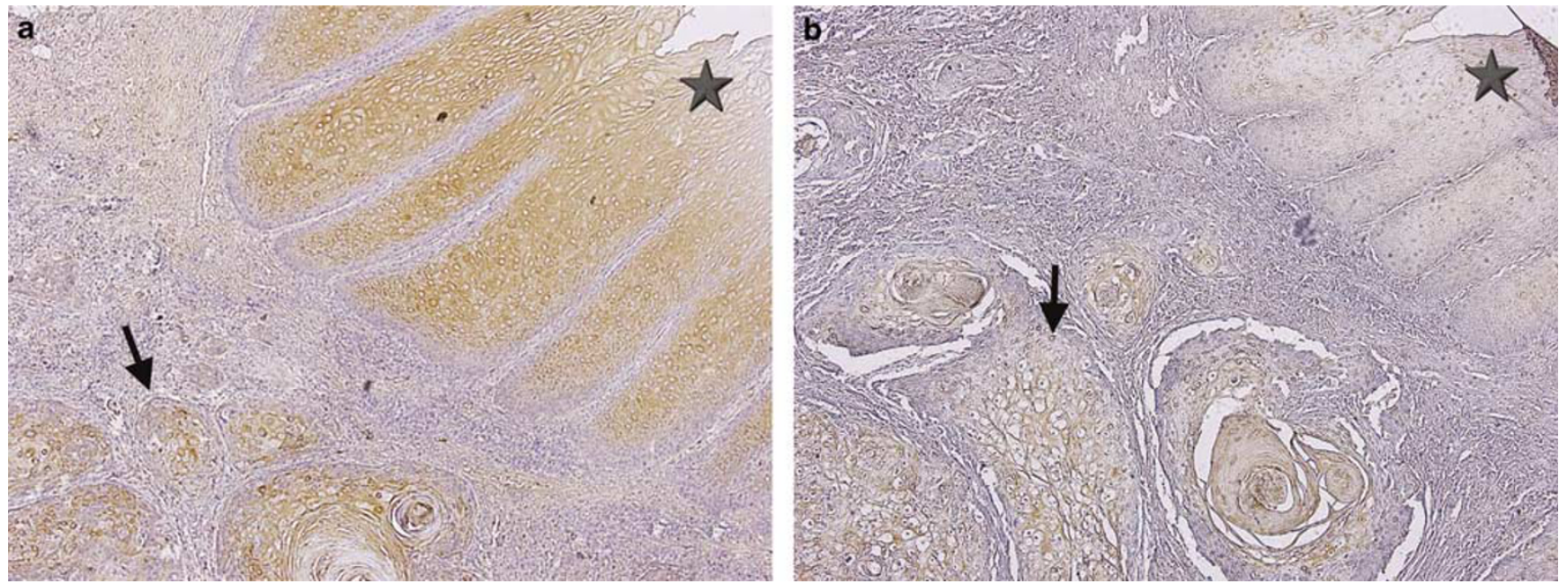

Figure 2 Immunostaining of MMP-7 in buccal squamous cell carcinoma. (a) Strong staining of MMP-7 in both cancer cells (arrows) and nonneoplastic epithelium (star) by using Ab-4 antibody against pro- and active forms of MMP-7. (b) Positive MMP-7 signal is present only in cancer cells by using Ab-2 antibody against active form of MMP-7 (original magnification, $\times 40$ ).
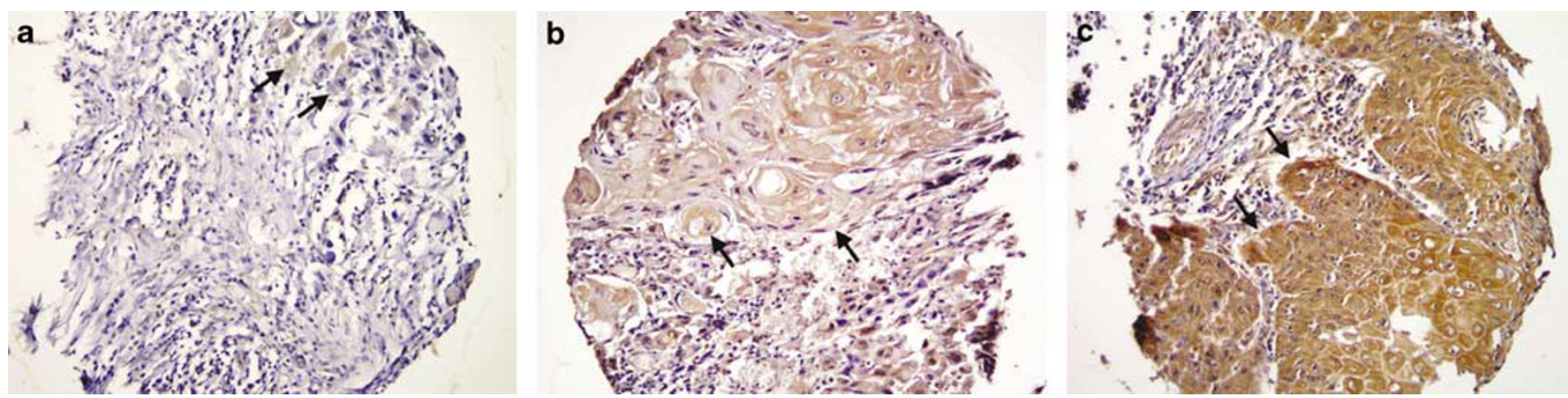

Figure 3 Tissue microarray immunostaining of active MMP-7 in buccal squamous cell carcinoma. (a) In a case graded as grade 1 of active MMP-7 expression, weak cytoplasmic staining is noted in of malignant squamous epithelial cells (arrows). (b) In a case graded as grade 2 of active MMP-7 expression, moderate cytoplasmic staining is noted in groups of malignant squamous epithelial cells (arrows). (c) In a case graded as grade 3 of active MMP-7 expression, strong cytoplasmic staining is noted in almost all the malignant squamous epithelial cells (arrows) (original magnification, $\times 200$ ).

microarray, to correlate the expression of active MMP-7 in tumors with the clinical features of all 24 patients.

\section{Increased Active MMP-7 Immunostaining Correlated with Advanced Buccal Cancer with Adjacent Tissue Invasion}

From a total of 24 patient samples available for tissue microarray analysis, low expression of active MMP-7 was noted in 15 cases (63\%) (Figures 3a and b), and high expression, in 9 (38\%) (Figure 3c). As shown in Table 2, high expression of active MMP-7 was associated with larger tumor size $(P=0.022)$ and was significantly higher in buccal squamous cell carcinoma with adjacent skin or bone invasion $(P=0.036)$. In those patients whose tumors showed mandibular bone invasion, we found tumor nests that stained strongly for active MMP-7, in sharp contrast to normal bone tissue (Figure 4).

The expression of active MMP-7 was not correlated with other parameters, including age, histologic grade, lymph node metastasis, tumor necrosis, perineural invasion, or vascular invasion.

\section{Discussion}

Oral squamous cell carcinoma is the sixth most common cancer in the world. In Taiwan, the betel quid chewing habit is an important risk factor for developing oral submucosal fibrosis and oral cavity cancer. Liao et $a l^{24}$ and Lo et $a l^{25}$ found both pathological nodal status and cell differentiation were the significant prognostic factors of 5-year disease-specific survival in buccal squamous cell carcinoma. Consequently, the clinicophathologic characteristics in Taiwanese are different from 
Table 2 Correlation between the clinicopathological features and the expressions of active MMP-7

\begin{tabular}{|c|c|c|c|c|}
\hline \multirow[t]{2}{*}{ Variables } & \multicolumn{4}{|c|}{ Active $M M P-7$} \\
\hline & $\begin{array}{c}\text { Low } \\
(\mathrm{n}=15)\end{array}$ & $\begin{array}{c}\text { High } \\
(\mathrm{n}=9)\end{array}$ & $\mathrm{P}$-value & $\begin{array}{c}\mathrm{P} \text {-value } \\
\text { for } \\
\text { linear } \\
\text { trend }\end{array}$ \\
\hline \multicolumn{5}{|l|}{ Age } \\
\hline$<50 \mathrm{y} / \mathrm{o}$ & 8 & 2 & 0.147 & \\
\hline$\geqq 50 \mathrm{y} / \mathrm{o}$ & 7 & 7 & & \\
\hline \multicolumn{5}{|l|}{ Stage } \\
\hline I & 5 & 0 & 0.058 & \\
\hline II & 2 & 2 & & \\
\hline III & 3 & 0 & & \\
\hline IV & 5 & 7 & & \\
\hline \multicolumn{5}{|l|}{ T stage } \\
\hline $\mathrm{T} 1$ & 5 & 0 & 0.056 & 0.022 \\
\hline $\mathrm{T} 2$ & 6 & 3 & & \\
\hline T3 & 1 & 0 & & \\
\hline $\mathrm{T} 4$ & 3 & 6 & & \\
\hline \multicolumn{5}{|l|}{ Nodal stage } \\
\hline Negative & 9 & 8 & 0.144 & \\
\hline Positive & 6 & 1 & & \\
\hline \multicolumn{5}{|c|}{ Histological grade } \\
\hline WD & 11 & 8 & 0.386 & \\
\hline MD & 4 & 1 & & \\
\hline \multicolumn{5}{|c|}{ Tumor thickness } \\
\hline$\leqq 10 \mathrm{~mm}$ & 10 & 4 & 0.306 & \\
\hline$>10 \mathrm{~mm}$ & 5 & 5 & & \\
\hline \multicolumn{5}{|c|}{ Tumor necrosis } \\
\hline Negative & 11 & 4 & 0.171 & \\
\hline Positive & 4 & 5 & & \\
\hline \multicolumn{5}{|c|}{ Perineural invasion } \\
\hline Negative & 10 & 7 & 0.582 & \\
\hline Positive & 5 & 2 & & \\
\hline \multicolumn{5}{|c|}{ Vascular invasion } \\
\hline Negative & 12 & 8 & 0.591 & \\
\hline Positive & 3 & 1 & & \\
\hline \multicolumn{5}{|c|}{ Adjacent tissue invasion } \\
\hline Negative & 12 & 3 & 0.036 & \\
\hline Positive & 3 & 6 & & \\
\hline
\end{tabular}

MD, moderate differentiated; MMP, matrix metalloproteinases; WD, well differentiated.

Westerner. The predominant sites of oral cavity cancer occurrence are the buccal mucosa, followed by the tongue in Taiwan. It is in contrast to the Western literature, in which the tongue and mouth floor are the main sites. ${ }^{22,25}$ In Taiwan, only $5-7 \%$ of oral cancer are graded as poorly differentiated type. $^{24,25}$ In our unpublished observation (H-C Chuang, unpublished observation), 1 of 118 documented patients $(<1 \%)$ with buccal squamous cell carcinoma in our hospital is graded as poorly differentiated type. Similar observation is reported in Japan, which reveals $4 \%$ of oral cancer is of poorly differentiated type. ${ }^{26}$ These data indicate that poorly differentiated oral cancer in Taiwan is significantly lower than the report of $21-42.8 \%$ in the Western countries. ${ }^{8,27}$ It is unknown if different location of the oral cancer, the different etiology or different races may account for the observed difference in the percentage of cell types.
MMP-7, also known as matrilysin-1, is the smallest member of the MMP family, ${ }^{15,28}$ as it lacks the C-terminal hemopexin domain common to other MMPs. MMP-7 is secreted as a $28-\mathrm{kDa}$ proenzyme and can be activated through proteolytic removal of a $9-\mathrm{kDa}$ prodomain from the $\mathrm{N}$ terminus. It is a protease with broad substrate specificity, ${ }^{15}$ being able to degrade elastin, proteoglycans, fibronectin, vitronectin, aggrecan, and type IV collagen, and it is important role in the shedding of cell-surface molecules such as tumor necrosis factor- $\alpha$ precursor, Fas ligand, heparin-binding epidermal growth factor, E-cadherin, $\beta 4$-integrin, and insulin-like growth factor-binding proteins. ${ }^{15,29}$

MMP-7 is constitutively expressed in exocrine and mucosal epithelial cells in the skin, pancreas, liver, breast, intestine, and lung. In cancers of the colon, ${ }^{30-33}$ esophagus, ${ }^{34}$ stomach, ${ }^{34-36}$ pancreas, ${ }^{37}$ breast $^{38}$ and prostate, ${ }^{39}$ increased MMP-7 expression is associated with tumor invasion, cancer progression, and poor prognosis. Two mechanisms may be responsible for the enhancement of cancer invasion and metastasis by MMP-7: direct effects of MMP-7 proteinase activity and indirect effects of MMP-7, such as activation of MMP-2 and MMP-9. ${ }^{38,40}$

Previous studies that did not use antibodies specific for active MMP-7 have produced conflicting results. For example, Sillanpaa et $a l^{41}$ and Leinonen et $a l^{42}$ found that high MMP-7 expression indicated less aggressive tumor behavior and better survival in ovarian and non-small-cell lung cancer. In their studies, normal ovarian epithelium and normal bronchial surface epithelial cells also showed positive MMP-7 staining, indicating antibody reactivity against the proMMP-7. In the present study, we also found MMP-7 in both normal buccal tissue and cancer tissue. However, immunoreactivity for active MMP-7 was present only in cancer tissue and was correlated with tumor size and tumor invasion of the adjacent skin and mandible, suggesting that MMP-7 is activated in tumor cells and is associated with aggressive tumor behavior in buccal cancer. Weber et $a l^{18}$ found that MMP-7 is mainly produced by tumor cells themselves and is associated with short survival times in head and neck cancer. de Vicente et $a l^{22}$ also demonstrated that MMP-7 expression is significantly correlated with lymph node metastasis in oral cavity cancers.

Our finding of adjacent bone invasion by buccal cancer cells that expressed high levels of active MMP-7 is consistent with a previous study of prostate cancer-induced osteolysis. ${ }^{39}$ The secretion of activated MMP-7 by cancer cells may cleave RANKL from the RANKL-expressing cancer cell, to release an active soluble form of RANKL and induce osteoclast activation and bone resorption. Bone degradation then allows the release of tumor growth factors such as insulin-like growth factor, transforming growth factor, and fibroblast growth factor, which stimulate the vicious cycle between the osteolytic process and tumor development in bone 

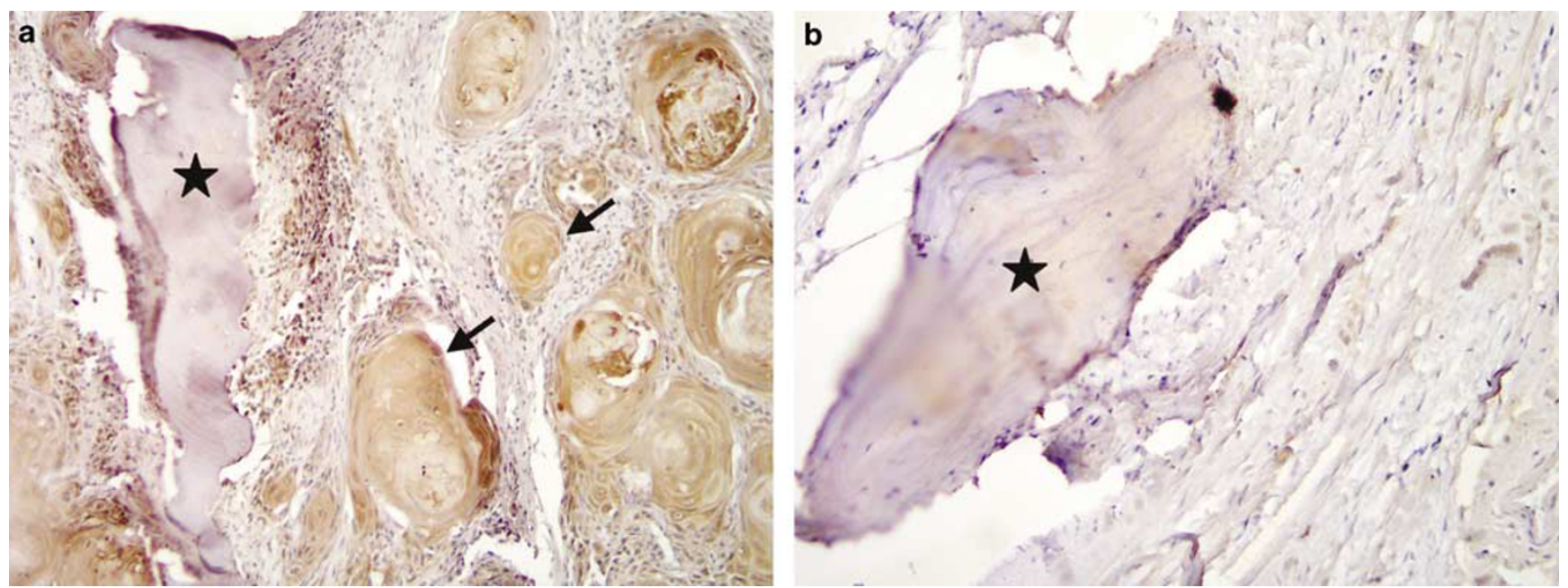

Figure 4 Immunostaining of active MMP-7 in a mandibular bone with or without buccal squamous cell carcinoma invasion. (a) The tumor nests immediately surrounding the bony tissue express strong immunostaining of active MMP-7 (arrows). (b) The stromal cells surrounding the bony tissue (star) without tumor invasion show no staining of active MMP-7 (original magnification, $\times 200$ ).

matrix. We have also seen strong immunoreactive RANKL expression in cancer cells that invaded mandibular bone (H-C Chuang, unpublished observations), suggesting a role for active MMP-7 in triggering the osteolyic RANK-RANKL signaling pathway in buccal cancer.

In summary, the present study appears to be the first report of an association between active MMP-7 and progression of buccal squamous cell carcinoma, which may involve the RANK-RANKL and/or other signaling pathways. Further studies are required to clarify the mechanism underlying the production of active MMP-7 in buccal squamous cell carcinoma.

\section{Acknowledgements}

We thank Assistant Professor Wei-Hsuan Yu, Institute of Biochemistry and Molecular Biology, National Taiwan University, for invaluable assistance and for providing the antibody used in this study, and Ming-Huei Chou and Chang-Han Chen for technical help. This study was supported by grants from the Chang Gung Memorial Hospital (CMRPG850162 and CMRPG860341).

\section{References}

1 Cancer Registry. Department of Health, Executive Yuan, Taiwan, Republic of China, 2006.

2 Chen YK, Huang HC, Lin LM, et al. Primary oral squamous cell carcinoma: an analysis of 703 cases in southern Taiwan. Oral Oncol 1999;35:173-179.

3 Jones AS, England J, Hamilton J, et al. Mandibular invasion in patiens with oral and oropharyngeal squamous cell carcinoma. Clin Otolaryngol Allied Sci 1997;22:239-245.
4 Thomas GT, Lewis MP, Speight PM. Matrix metalloproteinases and oral cancer. Oral Oncol 1999;35: 227-233.

5 Rosenthal EL, Matrisian LM. Matrix metalloproteases in head and neck cancer. Head Neck 2006;28: 639-648.

6 Sutinen M, Kainulainen T, Hurskainen T, et al. Expression of matrix metalloproteinases (MMP-1 and -2) and their inhibitors (TIMP-1, -2 and -3 ) in oral lichen planus, dysplasia, squamous cell carcinoma and lymph node metastasis. Br J Cancer 1998;77:2239-2245.

7 Kurahara S, Shinohara M, Ikebe T, et al. Expression of MMPS, MT-MMP, and TIMPs in squamous cell carcinoma of the oral cavity: correlations with tumor invasion and metastasis. Head Neck 1999;21: 627-638.

8 Franchi A, Santucci M, Masini E, et al. Expression of matrix metalloproteinase 1, matrix metalloproteinase 2 , and matrix metalloproteinase 9 in carcinoma of the head and neck. Cancer 2002;95:1902-1910.

9 Lin SC, Lo SS, Liu CJ, et al. Functional genotype in matrix metalloproteinases-2 promoter is a risk factor for oral carcinogenesis. J Oral Pathol Med 2004;33:405-409.

10 O-Charoenrat P, Khantapura P. The role of genetic polymorphisms in the promoters of the matrix metalloproteinase-2 and tissue inhibitor of metalloproteinase-2 genes in head and neck cancer. Oral Oncol 2006;42:257-267.

11 de Vicente JC, Fresno MF, Villalain L, et al. Expression and clinical significance of matrix metalloproteinase-2 and matrix metalloproteinase- 9 in oral squamous cell carcinoma. Oral Oncol 2005;41:283-293.

12 Liu WW, Zeng ZY, Wu QL, et al. Overexpression of MMP-2 in laryngeal squamous cell carcinoma: a potential indicator for poor prognosis. Otolaryngol Head Neck Surg 2005;132:395-400.

13 Patel BP, Shah PM, Rawal UM, et al. Activation of MMP-2 and MMP-9 in patients with oral squamous cell carcinoma. J Surg Oncol 2005;90:81-88.

14 de Vicente JC, Fresno MF, Villalain L, et al. Immunoexpression and prognostic significance of TIMP-1 and -2 in oral squamous cell carcinoma. Oral Oncol 2005;41:568-579. 
15 Ii M, Yamamoto $\mathrm{H}$, Adachi $\mathrm{Y}$, et al. Role of matrix metalloproteinase-7 (matrilysin) in human cancer invasion, apoptosis, growth, and angiogenesis. Exp Biol Med (Maywood) 2006;231:20-27.

16 Polette M, Nawrocki-Raby B, Gilles C, et al. Tumour invasion and matrix metalloproteinases. Crit Rev Oncol Hematol 2004;49:179-186.

17 Egeblad M, Werb Z. New functions for the matrix metalloproteinases in cancer progression. Nat Rev Cancer 2002;2:161-174.

18 Weber A, Hengge UR, Stricker I, et al. Protein microarrays for the detection of biomarkers in head and neck squamous cell carcinomas. Hum Pathol 2007;38:228-238.

19 O-Charoenrat P, Rhys-Evans PH, Eccles SA. Expression of matrix metalloproteinases and their inhibitors correlates with invasion and metastasis in squamous cell carcinoma of the head and neck. Arch Otolaryngol Head Neck Surg 2001;127:813-820.

20 Xie M, Sun Y, Li Y. Expression of matrix metalloproteinases in supraglottic carcinoma and its clinical implication for estimating lymph node metastases. Laryngoscope 2004;114:2243-2248.

21 Impola U, Uitto VJ, Hietanen J, et al. Differential expression of matrilysin-1 (MMP-7), $92 \mathrm{kD}$ gelatinase (MMP-9), and metalloelastase (MMP-12) in oral verrucous and squamous cell cancer. J Pathol 2004;202: $14-22$.

22 de Vicente JC, Lequerica-Fernandez P, Santamaria J, et al. Expression of MMP-7 and MT-1 MMP in oral squamous cell carcinoma as predictive indicator for tumor invasion and prognosis. J Oral Pathol Med 2007;36:415-424.

23 Vairaktairs E, Serefoglou Z, Yapijakis C, et al. High gene expression of matrix metalloproteinase-7 is associated with early stage of oral cancer. Anticancer Res 2007;27:2493-2498.

24 Liao CT, Wang HM, Ng SH, et al. Good tumor control and survivals of squamous cell carcinoma of buccal mucosa treated with radical surgery with or without neck dissection in Taiwan. Oral Oncol 2006;42:800-809.

25 Lo WL, Kao SY, Chi LY, et al. Outcomes of oral squamous cell carcinoma in Taiwan after surgical therapy: factors affecting survival. J Oral Maxillofac Surg 2003;61:751-758.

26 Katayama A, Bandoh N, Kishibe K, et al. Expression of matrix metalloproteinases in early-stage oral squamous cell carcinoma as predictive indicators for tumor metastasis and prognosis. Clin Cancer Res 2004;10: 634-640.

27 Pyo SW, Hashimoto M, Kim YS, et al. Expression of E-cadherin, P-cadherin and $\mathrm{N}$-cadherin in oral squamous cell carcinoma: correlation with the clinicopathologic features and patient outcome. J Craniomaxillofac Surg 2007;35:1-9.

28 Wilson CL, Matrisian LM. Matrilysin: an epithelial matrix metalloproteinase with potentially novel functions. Int J Biochem Cell Biol 1996;28:123-136.
29 Hemers E, Duval C, McCaig C, et al. Insulin-like growth factor binding protein-5 is a target of matrix metalloproteinase-7: implications for epithelialmesenchymal signaling. Cancer Res 2005;65:7363-7369.

30 Witty JP, McDonnell S, Newell KJ, et al. Modulation of matrilysin levels in colon carcinoma cell lines affects tumorigenicity in vivo. Cancer Res 1994;54:4805-4812.

31 Hasegawa S, Koshikawa $\mathrm{N}$, Momiyama $\mathrm{N}$, et al. Matrilysin-specific antisense oligonucleotide inhibits liver metastasis of human colon cancer cells in a nude mouse model. Int J Cancer 1998;76:812-816.

32 Leeman MF, Curran S, Murray GI. New insights into the roles of matrix metalloproteinases in colorectal cancer development and progression. J Pathol 2003; 201:528-534.

33 Adachi Y, Yamamoto $\mathrm{H}$, Itoh $\mathrm{F}$, et al. Contribution of matrilysin (MMP-7) to the metastatic pathway of human colorectal cancers. Gut 1999;45:252-258.

34 Zhang J, Jin X, Fang S, et al. The functional polymorphism in the matrix metalloproteinase-7 promoter increases susceptibility to esophageal squamous cell carcinoma, gastric cardiac adenocarcinoma and non-small cell lung carcinoma. Carcinogenesis 2005; 26:1748-1753.

35 McCaig C, Duval C, Hemers E, et al. The role of matrix metalloproteinase-7 in redefining the gastric microenvironment in response to Helicobacter pylori. Gastroenterology 2006;130:1754-1763.

36 Liu XP, Kawauchi S, Oga A, et al. Prognostic significance of matrix metallo proteinase-7 (MMP-7) expression at the invasion front in gastric carcinoma. Jpn J Cancer Res 2002;93:291-295.

37 Jones LE, Humphreys MJ, Campbell FC, et al. Comprehensive analysis of maxtrix metalloproteinase and tissue inhibitor expression in pancreatic cancer: increased expression of matrix metalloproteinase-7 predicts poor survival. Clin Cancer Res 2004;10: 2832-2845.

38 Wang F, Reierstad S, Fishman DA. Matrilysin overexpression in MCF-7 cells enhances cellular invasiveness and pro-gelatinase activation. Cancer Lett 2006;236:292-301.

39 Lynch CC, Hikosaka A, Acuff HB, et al. MMP-7 promotes prostate cancer-induced osteolysis via the solubilization of RANKL. Cancer Cell 2005;7:485-496.

40 Wang F, So J, Reierstad S, et al. Matrilysin(MMP-7) promotes invasion of ovarian cells by activation of progelatinase. Int J Cancer 2005;114:19-31.

41 Sillanpaa SM, Anttila MA, Voutilainen KA, et al. Prognostic significance of matrix metalloproteinases-7 in epithelial ovarian cancer and its relation to $\beta$-catenin expression. Int $\mathrm{J}$ Cancer 2006;119: 1792-1799.

42 Leinonen $\mathrm{T}$, Prinen R, Bohm J, et al. Expression of matrix metalloproteinase 7 and 9 in non-small cell lung cancer. Relation to clinicopathological factors, $\beta$-catenin and prognosis. Lung Cancer 2006;51:313-321. 